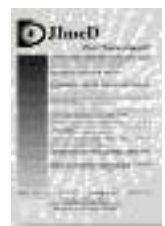

Jurnal Imejing Diagnostik (JImeD) 6 (2020) 60-64

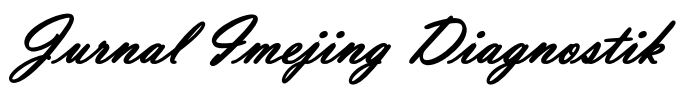

e-ISSN 2621-7457, p-ISSN 2356-301X

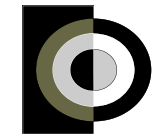

http://ejournal.poltekkes-

smg.ac.id/ojs/index.php/jimed/index

\title{
Nilai Contrast to Noise Ratio (CNR) Radiograf Thorax PA antara menggunakan Grid dengan tanpa Menggunakan Grid
}

\author{
Angga Yosainto Bequet ${ }^{1}$, Fatimah $^{2}$, Luthfi Rusyadi ${ }^{3}$ \\ ${ }^{12}$ Poltekkes Kemenkes Semarang, Indonesia \\ Corresponding author: Angga Yosainto Bequet \\ E-mail: anggayosainto@gmail.com
}

Received: March 16 ${ }^{\text {th }}, 2020$; Revised: June 17 $7^{\text {th }}$ 2020; Accepted: June $30^{\text {th }} 2020$

\begin{abstract}
Background: In the Thoracic Radiography Technique, applying the use of a grid to control scattered radiation almost never occurs, because the organ that is radiologically examined is classified as soft tissue dominance. Consideration of using grid is very important when the thickness of the thoracic organ exceeds $10 \mathrm{~cm}$, thus potentially increasing scattering radiation which will affect the value of the Contrast to Noise Ratio (CNR). The purpose of this study is to examine the difference between the use of grid and non-grid for the chest radiography techniques in the context of CNR values.

Methods: In the study, a hundred healthy patient uderwent the chest posteroanterior (PA) radiographic examination, a half of the total patients was examined with grid whereas the rest without the grid embedded. All the resulted images were analyzed by means of the pixel value measurements at the specific organs of interest (costea and pulmonary tissues) in inside and outside of the lung organs, using 1,5 $\mathrm{mm}$ of ROI from Dicom software. The statistical analysis of the CNR values was performed by comparing the results between the groups.

Results: There is a significant difference in the contrast values on the PA radiographs between those using the Grid and without using the Grid (p-value <0.001). The average contrast value on the chest radiograph with Grid is 2283.60 , while without Grid is 1878.58 . In the Noise values, it also deems significance (pvalue $=0.001)$. The average of the noise values employing the Grid in the technique is 25.32 , whereas without Grid is 17.84. In the Contrast to Noise Ratio (CNR), the diference seems to be significant (p-value $<0.001$ ). The average CNR radiograph of the PA chest using the Grid is 100.79 , while the non-grid is 125.62 .

Conclusions: The application of the grid in radiography technique gives significant difference in the image results (contrast, noise, and CNR), when compare to the radiographic techniques without the grid. Using the grid in the Technique improve the qPA-thoracic quality of the chest images.
\end{abstract}

Keyword: Chest; CNR; Thorax PA; Grid.

\section{Pendahuluan}

Pemeriksaan radiografi thorax merupakan pemeriksaan paling sering dan paling rutin dilakukan di setiap instalasi radiologi khususnya radiodiagnostik (WHO, 2016). Pemeriksaan radiografi thorax merupakan metode diagnostik yang cukup penting untuk mengevaluasi saluran pernafasan, parenkim dan pembuluh darah paru, mediastinum, jantung, pleura dan dinding thorax.

Menurut (Carlton \& Adler, 2001), objek dengan volume yang besar akan meningkatkan jumlah radiasi hambur. Radiasi hambur yang mengenai film akan mengganggu nilai diagnostik citra, karena pengaruh hamburan radiasi dan rendahnya signal (Forster, 1985). Obyek thorax dewasa ukuran pasien standar dengan ketebalan yang tinggi $(>10$ 
$\mathrm{cm})$ membutuhkan grid (penapis) untuk mengurangi insidensi radiasi hambur (Carlton \& Adler, 2001).

Peneliti menjumpai dilapangan, pemeriksaan radiografi thorax sering tidak menggunakan grid. Radiograf dibuat menggunakan grid jika prosedur radiografi thoraks dibuat dengan memanfaatkan bucky system, yang mana moving grid sudah tersedia di dalam perangkat alat. Jika bucky system tidak di gunakan maka prosedur radiografi cenderung tanpa memfungsikan grid (Bruce et al., 2012). Buruk nya pengendalian radiasi hambur dan kualitas signal menjadi masalah potensial yang berpengaruh terhadap kualitas citra.

Dari permasalahan tersebut, penelitian ini bertujuan untuk memeriksa kejadian hamburan radiasi melalui observasi terhadap perbedaan Contrast to Noise Ratio (CNR) radiograf thorax PA antara menggunakan grid dan tanpa menggunakan grid. Selain itu, observasi terhadap tingkat perubahan nilai CNR radiograf thorax PA antara menggunakan grid dan tanpa menggunakan grid juga di lakukan.

\section{Metode}

Penelitian ini merupakan jenis penelitian kuantitatif dengan disain eksperimental. 100 Subjek pasien terlibat dalam pemeriksaan radiologi thorax PA. 50 radiografi dari pasien dibuat dengan menggunaan grid dan 50 yang tersisa tanpa menggunakan grid.

Masing-masing citra diukur nilai pixelnya pada area obyek (costae dan paru), dan area diluar objek. Pengukuran dilakukan menggunakan software pengolah citra radiograf dengan cara memberikan ROI berukuran $1,5 \mathrm{~mm}$. Nilai contrast diperoleh dari selisih antara nilai pixel pada costae dengan nilai pixel pada area paru-paru. Nilai CNR diperoleh dari perbandingan antara nilai Contrast dengan nilai standar deviasi nilai pixel area diluar organ.

\section{Hasil dan Pembahasan}

Pengambilan data dilakukan untuk pasien pemeriksaan radiografi thorax pada bulan oktober 2019 dengan jumlah sampel sebanyak 100 pasien yang terdiri dari 50 pasien dilakukan pemeriksaan radiografi thorax dengan menggunakan Grid, dan 50 pasien tanpa menggunakan Grid.

Dari 100 pasien diketahui sebanyak 44 pasien berjenis kelamin laki-laki dan 56 pasien berjenis kelamin perempuan. Pasien yang diambil datanya pada ppenelitian ini adalah pasien rawat jalan yang mampu untuk dilakukan pemeriksaan radiografi thorax dengan cara berdiri seperti tampak pada gambar 1 dan 2 .

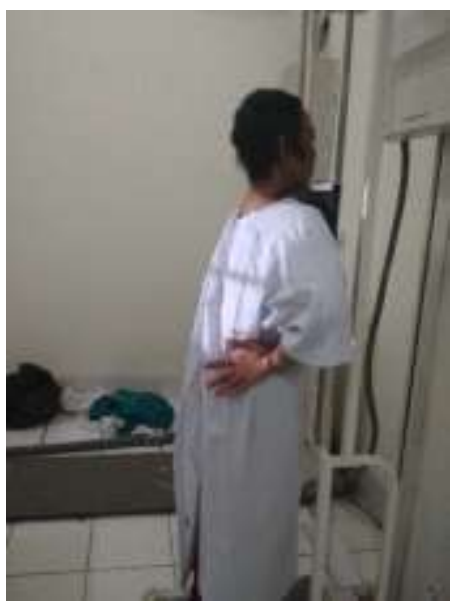

Gambar 1. Posisi Pasien Pemeriksaan Thorax tanpa Grid

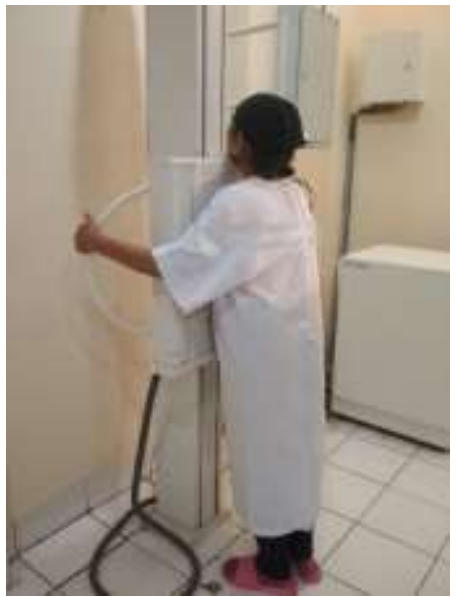

Gambar 2. Posisi Pasien Pemeriksaan Thorax dengan Grid

Masing-masing citra diukur nilai pixelnya pada daerah costae, paru dan area kosong diluar objek yang difoto untuk menentukan nilai noise. Pengukuran dilakukan menggunakan software pengolah citra radiograf dengan cara memberikan ROI berukuran $1,5 \mathrm{~mm}$. Nilai contrast diperoleh dari selisih antara nilai pixel pada costae dengan nilai pixel pada area paru-paru. Nilai CNR diperoleh dari perbandingan antara nilai Contrast dengan nilai standar deviasi nilai pixel area diluar organ seperti tampak pada gambar 3 . 


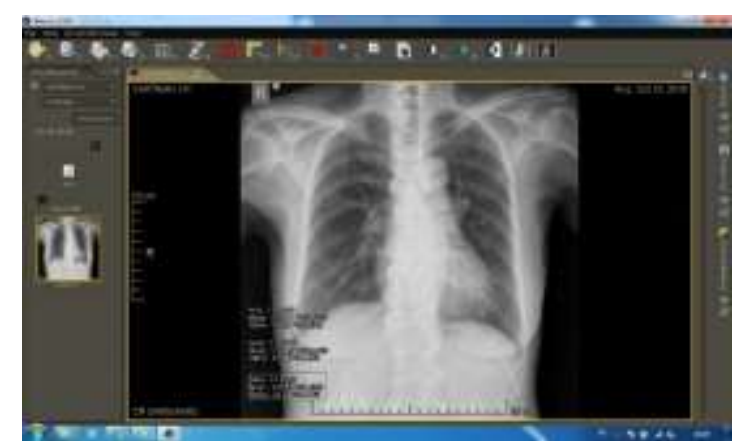

Gambar 3. Pengukuran nilai pixel menggunakan software DICOM

Analisis univariat bertujuan untuk mengetahui homogenitas dari sampel yang digunakan meliputi Body Mass Index, penggunaan $\mathrm{kV}$ dan $\mathrm{mAs}$ pada pebguatan radiograf thorax antara dengan penggunaan Grid dan tanpa penggunaan Grid. Hasil uji homogenitas disajikan pada tabel 1 .

Tabel 1. Uji Homogenitas sampel

\begin{tabular}{llll}
\hline No & Karakteristik & p-value & Keterangan \\
\hline 1 & Body Mass Index & 0,979 & Homogen \\
\hline 2 & $\mathrm{kV}$ & 0,252 & Homogen \\
\hline 3 & $\mathrm{mAs}$ & 0,188 & Homogen \\
\hline
\end{tabular}

Dari tabel 1 diatas diketahui bahwa kondisi pasien yang digunakan sebagai sampel penelitian adalah homogen, begitu pula dengan faktor eksposi yang digunakan meliputi nilai $\mathrm{kV}$ dan $\mathrm{mAs}$.

Setelah dilakukan pengukuran menggunakan ROI dan diketahui nilai contrast, noise dan Contrast to Noise Ratio, selanjutnya data dilakukan analisa secara statistik untuk mengetahui ada tidaknya perbedaan nilai contras, noise dan Contrast to Noise Ratio Radiograf foto thorax antara menggunakan Grid dengan tanpa menggunakan Grid. Hasil uji statistik disajikan pada tabel dibawah ini.

Tabel 2. Uji Statistik radiograf Thorax PA antara menggunakan Grid dengan tanpa menggunakan Grid

\begin{tabular}{llccll}
\hline \multirow{2}{*}{ No } & Variabel & \multicolumn{2}{c}{$\begin{array}{c}\text { Rerata Hasil } \\
\text { Pengukuran }\end{array}$} & $\begin{array}{c}\text { p- } \\
\text { value }\end{array}$ & Keterangan \\
\cline { 2 - 5 } & Grid & $\begin{array}{c}\text { Tanpa } \\
\text { Grid }\end{array}$ & & \\
\hline 1 & Contrast & 2283,60 & 1878,58 & 0,001 & $\begin{array}{l}\text { Ada } \\
\text { perbedaan }\end{array}$ \\
\hline 2 & Noise & 25,32 & 17,84 & 0,001 & $\begin{array}{l}\text { Ada } \\
\text { perbedaan }\end{array}$ \\
\hline 3 & $\begin{array}{l}\text { Contrast } \\
\text { to Noise } \\
\text { Ratio }\end{array}$ & 100,79 & 125,62 & 0,001 & $\begin{array}{l}\text { Ada } \\
\text { perbedaan }\end{array}$ \\
\hline
\end{tabular}

Dari tabel diatas diketahui bahwa uji statistik menunjukkan terdapat perbedaan nilai contrast pada radiograf foto thorax PA antara yang menggunakan
Grid dengan tanpa menggunakan Grid (p-value < $0,001)$. Rata-rata nilai contrat pada radiograf foto thorax menggunakan Grid adalah 2283,60, sedangkan yang tanpa menggunakan Grid adalah 1878,58. Nilai Noise juga menunjukkan terdapat perbedaan antara radiograf foto thorax PA menggunakan Grid dengan tanpa menggunakan Grid ( $p$-value $=0,001)$. Rata-rata nilai noise radiograf foto thorax.menggunakan Grid adalah 25,32, sedangkan radiograf thorax tanpa menggunakan Grid adalah 17,84. Uji statistik terhadap nilai Contrast to Noise Ratio (CNR) juga menunjukkan terdapat perbedaan antara radiograf foto thorax PA menggunakan Grid dengan tanpa Grid (p-velue < 0,001). Rata-rata nilai CNR radiograf thorax PA dengan menggunakan Grid adalah 100,79, sedangkan nilai CNR radiograf thorax PA tanpa menggunakan Grid adalah 125,62.

\section{Perbedaan nilai Contrast Citra antara radiograf thorax PA menggunakan Grid dengan tanpa Grid}

Grid adalah perangkat berbentuk segi empat pipih dibuat ari serangkaian strip timbal yang bersifat radioopaq yang dipisahkan oleh material yang bersifat radioluscent secara berurutan. Material radioluscent yang biasa digunakan adalah alumunium (Carlton \& Adler, 2001). Penggunaan grid didalam proses radiografi diletakkan diantara pasien dan film (Bushong, 2013).

Contras citra merupakan perbedaan tingkat kehitaman pada suatu citra radiograf. Pada citra analog yang berbasis screen-film, contrast diartikan sebagai perbedaan optical density (OD) (Bushong, 2013). Pada citra digital contrast merupakan ukuran perbedaan antara nilai data (pixel value) (Carlton \& Adler, 2001).

Fungsi contrast dalam citra adalah untuk membuat suatu struktur anatomi menjadi lebih terlihat. Contrast citra merupakan faktor paling penting dalam kualitas suatu citra radiograf. (Bushong, 2013).

Hasil penelitian menunjukkan bahwa terdapat perbedaan nilai contrast pada radiograf thorax PA antara menggunakan Grid dengan tanpa menggunakan Grid. Radiograf thorax PA yang menggunakan Grid memiliki nilai contrast yang lebih tinggi jika dibandingkan dengan radiograf thorax PA tanpa menggunakan Grid dimana nilai rata-rata contras citra radiograf menggunakan Grid adalah 2283,60, sedangkan yang tanpa menggunakan Grid adalah 1878,58. Penggunaan Grid mampu meningkatkan nilai Contrast pada citra khususnya radiograf thorax dikarenakan penggunaan Griid akan menahan radiasi hambur 
(scatter radiation) yang akan mengenai image receptor (Bushong, 2013).

Grid memiliki fungsi untuk menyerap radiasi hambur sebelum radiasi hambur tersebut mengenai film. Radiasi hambur adalah radiasi yang arahnya terdeviasi terhadap berkas utama. Efek dari radiasi hambur adalah selalu menghilangkan atau menutupi gambaran informasi dari radiograf (Forster, 1985). Radiasi hambur muncul akibat dari interaksi berkas radiasi utama dengan materi yang dilewatinya seperti tubuh pasien. Radiasi hambur yang mengenai film tidak akan membawa informasi diagnostik dari pasien, melainkan hanya menambah tingkat keabuan terhadap film, sehingga tidak memiliki nilai diagnostik. Selain itu, radiasi hambur juga akan menurunkan tingkat contrast pada citra (Carlton \& Adler, 2001).

Radiasi hambur adalah radiasi yang arahnya terdeviasi terhadap berkas utama. Efek dari radiasi hambur adalah selalu menghilangkan atau menutupi gambaran informasi dari radiograf (Forster, 1985).

Sesuai dengan hasil penelitian yang mana nilai contras radiograf foto thorax PA memiliki nilai contrast lebih tinggi jika dibandingkan dengan radiograf thorax PA tanpa menggunakan Grid dimana rata-rata nilai contras dengan menggunakan grid adalah 2283,60, sedangkan yang tanpa menggunakan Grid adalah 1878,58. Dengan contrast yang tinggi maka akan jelas perbedaan tampilan antara tulang dengan soft tissue (Bushong, 2013). Seperti pada radiografi thorax PA yang mana secara struktur terdiri dari tulang (costae, vertebrae, sternum, clavicula, dll) serta soft tissue (jaringan paru, pembuluh darah, bronkus paru, dll).

\section{Perbedaan Noise Citra antara radiograf thorax PA menggunakan Grid dengan tanpa Grid}

Noise juga merupakan salah satu bagian yang tidak dapat dipisahkan dari sistem pencitraan radiography. Noise pada radiografi adalah fluktuasi acak nilai optical density (pixel value pada citra digital) pada suatu citra. Noise merupakan gangguan acak yang mengaburkan atau mengurangi kejelasan citra. Dalam citra radiografi, noise diterjemahkan menjadi tampilan kasar atau berbintik-bintik pada citra (Bontrager \& Lampignano, 2014). Noise juga diartikan sebagai informasi latar yang bersifat acak yang terdeteksi oleh detektor dan tidak memberikan kontribusi kepada kualitas citra (Carlton \& Adler, 2001).

Hasil penelitian menunjukkan bahwa terdapat perbedaan tingkat noise antara radiografi thorak PA menggunakan grid dengan radiografi PA tanpa menggunakan grid ( $p$-value $=0,001$ ). Nilai noise pada radiograf thorax PA yang menggunakan Grid lebih tinggi dari pada nilai noise pada radiograf yang tidak menggunakan grid. hal ini dikarenakan penggunaan Grid akan meningkatkan quantum motle pada citra radiograf.

Ada empat komponen pada noise yaitu flm graininess, structure mottle, quantum mottle, and scatter radiation (Bushong, 2013). Penggunaan Grid mampu menurunkan nilai radiasi hambur (scatter radiation) dikarenakan grid akan memblok radiasi hambur yang terpancar dari pasien sebelum mengenai ke film / imaging plate. Namun penggunaan Grid juga akan memblok sebagian radiasi remnant yang akan mengenai film / imaging plate akibat adanya kisi kisi dari Grid sehingga intensitas radiasi yang mengenai film / imagig plate akan berkurang.

Quantum motle sebagai salah satu komponen dalam timbulnya noise akan meningkat manakala citra dihasilkan dari sedikit intensitas sinar-X. penggunaan grid akan mengurangi jumlah intensitas yang mengenai imaging plate sebagai dasar pembentukan citra. Quantum mottle yang tinggi pada citra akan tampak seperti tampilan grass seed yang disebar.

Untuk menjaga quantum mottle tetap rendah sehingga noise tetap rendah, maka penggunaan Grid pada radiografi thorax PA harus diimbangi dengan penabahan nilai $\mathrm{mAs}$ untuk menjaga agar intensitas sinar-X yang mengenai film tetap adekuat dalam menghasilkan citra

\section{Perbedaan Contrast to Noise Ratio Citra antara radiograf thorax PA menggunakan Grid dengan tanpa Grid}

Contrast to Noise Ratio (CNR) Merupakan perbandingan antara nilai contras terhadap noise suatu citra radiograf. CNR merupakan indikator relatif kualitas sebuah citra. Suatu ctra yang bagus akan memperlihatkan lesi dengan baik manakala nilai contrast meningkat sedangkan noisenya turun (rendah) (Huda \& Abrahams, 2015).

Hasil penelitian menunjukkan terdapat perbedaan nilai CNR antara radiograf thorax PA yang menggunakan grid dengan radiograf thorax PA tanpa menggunakan grid dengan p-value < 0,001. Nilai CNR radiograf thorax PA menggunaan grid memiliki nilai CNR lebih rendah $(100,79)$ jika dibandingan dengan nilai CNR radiograf thorax PA tanpa menggunakan Grid.

Penurunan nilai CNR pada radiograf thorax PA yang menggunakan Grid dikarenakan pada saat menggunakan grid, nilai noise pada radiograf meningkat akibat kenaikan quantum mottle, sehingga nilai CNR menjadi turun. Nilai CNR dapat menjadi salah satu indikator kualitas citra radiograf. 
Semakin baik nilai CNR dapat dikatakan kualitas citra juga semakin baik. Nilai CNR yang tinggi akan menghasilkan citra yang mampu menampilkan struktur anatomi dan patologi yang terlihat jelas.

Untuk dapat meningkatkan nilai CNR yang tinggi pada teknik radiografi thorax PA dengan menggunakan grid, maka perlu dilakukan modifikasi faktor eksposi dengan cara meningkatkan nilai mAs. Peningkatan nilai $\mathrm{mAs}$ pada teknik radiografi thorax menggunakan grid akan menjaga intensitas sinar-X yang mengenai film sehingga menjaga kenaikan nilai quantum mottle.

\section{Simpulan}

Terdapat perbedaan signifikan antara radiograf thorax PA menggunakan grid dan tanpa menggunakan grid pada nilai Contrast pada ( $\mathrm{p}$-value $<0,001$ ), Noise (p-value 0,001), dan CNR (p-value $<0,001)$.

Nilai contrast Radiograf thorax PA dengan grid lebih tinggi dari pada radiograf tanpa grid, hal sebalik nya terjadi pada nilai Noise dan CNR.

\section{Daftar Pustaka}

Bontrager, K. L., \& Lampignano, J. P. (2014). Textbook of Radiographic Positioning and Related Anatomy (8th ed.). Elsevier Mosby.

Bruce, W. long, Jeannean, H. R., \& Barbara, J. S. (2012). Merills Atlas of Radiographic Positioning \& Procedures.

Bushong, S. C. (2013). Radiologic Science for Technologist: Physics, Biology, and Protection.

Carlton, R. R., \& Adler, A. M. (2001). Principles of Radiographic Imaging An Art and Science 3rd Edition (Third Edition).

Forster, E. (1985). Equipment for Diagnostic Radiography. MTP Press Limited.

Huda, W., \& Abrahams, R. B. (2015). Radiographic Techniques, Contrast, and Noise in X-Ray Imaging. American Journal of Roentgenology, 204(2), $126-131$. https://doi.org/10.2214/AJR.14.13116

WHO. (2016). Communicating Radiation Risks in Paediatric Imaging: Information to support healthcare discussions about benefit and risk (World Health Organization, Ed.). 